\title{
$\operatorname{Au(111)~}$ 表面上乙醇选择性氧化反应机理的密度泛函理论研究
}

\author{
孟庆森 ${ }^{1}$, 申勇立 ${ }^{1}$, 徐 晶 ${ }^{2}$, 巩金龙 ${ }^{1, *}$ \\ ${ }^{1}$ 天津大学化工学院绿色合成与转化教育部重点实验室, 天津 300072 \\ 华东理工大学化学工程国家重点实验室, 上海 200237
}

\begin{abstract}
摘要: 采用密度泛函理论研究了吸附有 $\mathrm{O}$ 原子的 $\mathrm{Au}(111)$ 表面上乙醇选择性氧化的反应机理. 反应结果表明, 除 $\mathrm{O}$ 原子和中 间产物二齿醋酸根 $\left(\mathrm{CH}_{3} \mathrm{CHOO}\right)$ 外, 其他中间产物在 $\mathrm{Au}(111)$ 表面扩散能垒均较低, 不会对反应速控步骤的确定造成影响. 乙醇 羟基氧化脱氢为反应的第一步骤, 当氧化剂为吸附态的 $\mathrm{O}$ 原子或者为 $\mathrm{OH}$ 基时, 反应活化能分别为 0.20 和 $0.17 \mathrm{eV}$. 氧化产物 乙氧基 $\left(\mathrm{CH}_{3} \mathrm{CH}_{2} \mathrm{O}\right)$ 进一步氧化脱氢生成乙醛则需要表面吸附的 $\mathrm{O}$ 原子或另一表面吸附的 $\mathrm{OH}$ 基的参与, 所需活化能为 0.29 或 $0.27 \mathrm{eV}$. 同时, 乙醛易与表面吸附的乙氧基反应生成乙氧基半缩醛 $\left(\mathrm{CH}_{3} \mathrm{CHOOC}_{2} \mathrm{H}_{5}\right)$, 其可进一步与 $\mathrm{O}$ 原子作用, 脱氢形成 乙酸乙酯. 此外, 在乙醛深度氧化成酸的过程中需要克服较高的反应能垒, 因而在表面反应温度较低时无法进行, 这与实验结 果相符.
\end{abstract}

关键词: 反应机理; 选择性氧化; 乙醇; 金(111)；密度泛函理论

中图分类号: O643 文献标识码: A

收稿日期: 2011-10-12. 接受日期: 2011-11-28.

*通讯联系人. 电话/传真: (022)87401818; 电子信箱: jlgong@tju.edu.cn 基金来源: 国家自然科学基金(21006068); 教育部新世纪优秀人才支持计划(NCET-10-0611); 高等学校学科创新引智计划 (B06006)

本文的英文电子版(国际版)由Elsevier出版社在ScienceDirect上出版(http://www.sciencedirect.com/science/journal/18722067).

\section{Mechanistic Insights into Selective Oxidation of Ethanol on Au(111): A DFT Study}

\author{
MENG Qingsen ${ }^{1}$, SHEN Yongli ${ }^{1}$, XU Jing ${ }^{2}$, GONG Jinlong ${ }^{1, *}$ \\ ${ }^{1}$ Key Laboratory for Green Chemical Technology of Ministry of Education, School of Chemical Engineering and Technology, \\ Tianjin University, Tianjin 300072, China \\ ${ }^{2}$ State Key Laboratory of Chemical Engineering, East China University of Science and Technology, Shanghai 200237, China
}

\begin{abstract}
The reaction mechanism of selective oxidation of ethanol on $\mathrm{Au}(111)$ covered with atomic oxygen was described employing density functional theory calculations. The first step, dissociation of the $\mathrm{O}-\mathrm{H}$ bond in ethanol, has lower barrier for transfer of the $\mathrm{H}$ to adsorbed oxygen or surface hydroxyl than to gold with a barrier of 0.20 or $0.17 \mathrm{eV}$, respectively. The two lower activation energies for the $\beta$ - $\mathrm{H}$ elimination of ethoxyl, 0.29 and $0.27 \mathrm{eV}$, come from transfer of $\mathrm{H}$ atom to surface $\mathrm{O}$ atom or another ethoxyl. Ethyl acetate is formed through the $\beta-\mathrm{H}$ elimination of ethoxy hemiacetal. The formation of acetic acid is not facile through the reaction between the surface hydroxyl and acetaldehyde or between the surface oxygen and acetaldehyde at low temperature due to a high activation barrier. Except for surface oxygen and bidentate acetate, all other surface species have low diffusion barriers, suggesting that rearrangement and movement of these species from the preferred adsorption sites to the ideal configurations for reactions are facile.
\end{abstract}

Key words: mechanism; selective oxidation; ethanol; $\mathrm{Au}(111)$ surface; density functional theory

Received 12 October 2011. Accepted 28 November 2011.

*Corresponding author. Tel/Fax: +86-22-87401818; E-mail: jlgong@tju.edu.cn

This work was supported by the National Natural Science Foundation of China (21006068), the Program for New Century Excellent Talents in University (NCET-10-0611), and the Program of Introducing Talents of Discipline to Universities (B06006).

English edition available online at Elsevier ScienceDirect (http://www.sciencedirect.com/science/journal/18722067). 
Gold-based catalysis has attracted numerous attention due to its potential application for low-temperature and highly selective oxidative reactions [1-6]. Application of Au-based catalysts has been rapidly expanded to a broad range of reactions, such as alcohol oxidation [7-19], olefin opoxidation [20-24], and cross-oxidation reactions [25-28]. Alcohol oxidation is of particular interest because it is one of the key transformations in the organic synthesis for production of commodity chemicals.

Selective oxidation of alcohols to varbonylic compounds over heterogeneous catalysts is an important process in green organic chemistry [29]. Considerable efforts in recent years have been made on the aerobic oxidation that uses molecular oxygen as an oxidant, generating water as the only byproduct. A heterogeneous catalytic system for this reaction primarily focuses on transition metals such as $\mathrm{Ru}$ [30,31], Ag [32,33], Cu [34,35], Au [36-40], or Pd [41-43]. A number of studies [29-32,37,40] on the mechanism for aerobic alcohol oxidation show that the reaction starts with the formation of a metal-allkoxy species, which further undergoes a $\beta$-hydride elimination generating carbonylic products and a metal-hydrideintermediate. Additionally, unconventional metal particles in colloidal solutions [44] or supported on carbon $[33,45,46]$, silica $[38,40,42,43]$ or metal organic frameworks (MOFs) $[47,48]$ are highly active for alcohol oxidation, even in the absence of a base [47].

A number of investigations on oxidation of alcohols over $\mathrm{Au}$ model catalysts have been carried out to better understand the reaction pathways [7,8,15,17-19,49-57]. It has been reported that the oxygen-activated $\mathrm{Au}(111)$ is readily stripped hydrogen from alcohols to formed corresponding ketones or aldehydes [17,55] or able to mediate self-coupling of alcohols [7,8] and cross-coupling between alcohols and aldehydes [25,26,28], to the corresponding esters. Recently, molecular-level reaction mechanism of the selective oxidation of alcohols (mainly methanol, ethanol, propanol, and butanol) on the oxygen pre-covered gold surface has been studied experimentally $[8,17,19,25]$ and theoretically $[52,56,57]$. However, few of them have reported a detailed mechanism for the stepwise oxidation of alcohols on Au surface.

Herein, we present a systematic DFT study regarding elementary reaction steps and energy landscapes for the formation of acetaldehyde, acetic acid, and ethyl acetate on the $\mathrm{Au}(111)$ surface, which combines the identified or proposed mechanisms that have been reported experimentally [8,17]. The energetics and reaction barriers obtained from DFT calculations are consistent with the experimental observations and could provide a more detailed understanding regarding the origin of reactivity of oxidation of ethanol on gold.

\section{Theoretical method}

All DFT calculations were performed using the CASTEP program package in Materials Studio (version 3.0) with the GGA-PW91 functional [58] to describe election exchange and correlation. The ionic core is represented by ultrasoft pseudopotentials [59], and a $400 \mathrm{eV}$ cut-off energy was used. All the results come from non-spin polarization calculations [57] with density mixing scheme [60]. We applied Monkhorst-Pack [61] mesh k-points of $(3 \times 3 \times 1)$ for surface calculations, and a Fermi smearing of $0.1 \mathrm{eV}$ was used to improve the calculation performance. The convergence criteria were $2 \times 10^{-6} \mathrm{eV}$ for SCF, $2 \times 10^{-5} \mathrm{eV} /$ atom for electronic structure, and $0.5 \mathrm{eV} / \mathrm{nm}$ for forces.

The $\mathrm{Au}(111)$ surface was modeled by a four-layer slab in the $(111)$ direction, a $\mathrm{p}(3 \times 3)$ unit cell in the lateral directions, and a vacuum of $1.5 \mathrm{~nm}$ between slabs. During the optimization, the atoms in the top two metal layers and adsorbates were allowed to relax, and the atoms in the bottom two layers were fixed at the ideal bulk positions. The bulk gold positions of the bottom layer were taken from the calculated lattice constant of $0.407 \mathrm{~nm}$, which is in good agreement with the experimental value of $0.408 \mathrm{~nm}$ [57].

Adsorption energies, $E_{\text {ads }}$, were calculated as:

$$
E_{\text {ads }}=E_{\text {ad/sub }}-E_{\text {ad }}-E_{\text {sub }}
$$

where $E_{\mathrm{ad} / \mathrm{sub}}, E_{\mathrm{ad}}$, and $E_{\text {sub }}$ represent the total energies of the optimized adsorbate-substrate system, the adsorbate in gas phase, and the clean substrate, respectively. The reaction energies $\left(E_{\mathrm{r}}\right)$ of elementary reactions on the substrate were calculated as:

$$
E_{\mathrm{r}}=\sum E_{\text {products }}-\sum E_{\text {reactants }}
$$

where the $\sum E_{\text {products }}$ and $\sum E_{\text {reactants }}$ are the sum of the energies of the products and reactants. The negative value of $E_{\text {ads }}$ and $E_{\mathrm{r}}$ represents an exothermic and energetically favorable process and the positive value indicates that the process is endothermic and energetically unfavorable.

Possible transition states (TSs) were located by using the complete linear and quadratic synchronous transit (LST/QST) method connecting the reactants and products. The activation energy $\left(E_{\mathrm{a}}\right)$ of each elementary reaction was calculated by the energy difference between the TS and the initial state. All TSs were confirmed by the vibrational frequency analysis. The convergence criteria were set to 0.05 $\mathrm{eV}$, and the zero-point energies were included in present work.

\section{Results and discussion}

\subsection{Structures and energetics of adsorbed intermediates}


Optimized structures and calculated adsorption energetics of intermediates involved in the reaction of ethanol and oxygen on $\mathrm{Au}(111)$ primarily, include five saturated molecules $\left(\mathrm{H}_{2} \mathrm{O}, \mathrm{C}_{2} \mathrm{H}_{5} \mathrm{OH}, \mathrm{CH}_{3} \mathrm{CHO}, \mathrm{CH}_{3} \mathrm{COOH}\right.$, and $\left.\mathrm{CH}_{3} \mathrm{COOC}_{2} \mathrm{H}_{5}\right)$ and seven radicals $\left(\mathrm{H} \cdot \mathrm{O} \cdot \mathrm{O} \cdot \mathrm{OH}, \mathrm{CH}_{3} \mathrm{CH}_{2} \mathrm{O} \cdot\right.$, $\mathrm{CH}_{3} \mathrm{CHOOH}, \mathrm{CH}_{3} \mathrm{CHOO}$, and $\mathrm{CH}_{3} \mathrm{CHOOC}_{2} \mathrm{H}_{5}$ ). Calculated adsorption energies of the intermediates at the favorable sites are listed in Table 1, and the corresponding configurations are shown in Fig. 1.

Table 1 The most stable adsorption sites and adsorption energies of the intermediates involved in the selective oxidation reaction on the $\mathrm{Au}(111)$ surface

\begin{tabular}{|c|c|c|}
\hline Species & Adsorption site & $E_{\text {ads }}{ }^{\mathrm{a}} / \mathrm{eV}$ \\
\hline $\mathrm{H} \cdot$ & fcc & -2.11 \\
\hline $\mathrm{O}$ & fcc & -3.09 \\
\hline$\cdot \mathrm{OH}$ & bridge: through $\mathrm{O}$ & -1.70 \\
\hline $\mathrm{H}_{2} \mathrm{O}$ & top: through $\mathrm{O}$ & -0.11 \\
\hline $\mathrm{CH}_{3} \mathrm{CH}_{2} \mathrm{OH}$ & top: through $\mathrm{O}$ & -0.09 \\
\hline $\mathrm{CH}_{3} \mathrm{CH}_{2} \mathrm{O}$ & fcc: through $\mathrm{O}$ & -0.81 \\
\hline $\mathrm{CH}_{3} \mathrm{CHO}$ & parallel to surface & -0.05 \\
\hline $\mathrm{CH}_{3} \mathrm{CHOO}$ & bridged: O-bridge, O-bridge & -1.59 \\
\hline $\mathrm{CH}_{3} \mathrm{CHOOH}$ & bridged: O-bridge, O-top & -0.89 \\
\hline $\mathrm{CH}_{3} \mathrm{COOH}$ & parallel to surface & -0.13 \\
\hline $\mathrm{CH}_{3} \mathrm{CHOOC}_{2} \mathrm{H}_{5}$ & bridged: O-bridge, O-top & -0.86 \\
\hline $\mathrm{CH}_{3} \mathrm{COOC}_{2} \mathrm{H}_{5}$ & $\begin{array}{l}\text { parallel to surface, } \mathrm{C}-\mathrm{C} \text { of ethoxy } \\
\text { perpendicular to surface }\end{array}$ & -0.10 \\
\hline
\end{tabular}

${ }^{\mathrm{a}}$ Zero-point energies are included.

Water, ethanol, acetic acid, and ethyl acetate are bound weakly to the $\mathrm{Au}(111)$ surface through their oxygen atoms. The hydroxyls of adsorbed water are paralleled to the surface with the $\mathrm{O}-\mathrm{Au}$ bond lengths of $0.27 \mathrm{~nm}$, and calculated adsorption energies of water is $-0.11 \mathrm{eV}$. The $\mathrm{C}-\mathrm{O}$ axis of adsorbed ethanol is tilted relative to the normal of the substrate about $23^{\circ}$ and the bond length of $\mathrm{O}-\mathrm{Au}$ is $0.29 \mathrm{~nm}$, while the $\mathrm{C}-\mathrm{C}$ bond is paralleled to the substrate. For acetic acid adsorption (Fig. 1(j)), oxygen atoms in $\mathrm{CH}_{3} \mathrm{CO}-$ and $-\mathrm{OH}$ groups are most close to the surface, while the $\mathrm{C}-\mathrm{C}$ bond is paralleled to the surface; the adsorption energy is $-0.13 \mathrm{eV}$. Ethyl acetate also prefers to adsorb with its two $\mathrm{O}$ atoms most close to the surface, and the adsorption energy is $-0.10 \mathrm{eV}$. The aldehyde is weakly adsorbed and does not have preferred adsorption geometry, which is similar with formaldehyde reported earlier [56,57].

Ethoxy prefers to adsorb at fcc hollow sites via its oxygen atoms coordinate to the surface, while $\mathrm{C}-\mathrm{O}$ bond is almost vertical to the substrate with $\mathrm{C}-\mathrm{C}$ bond parallel to the surface. Bidentate acetate $\left(\mathrm{CH}_{3} \mathrm{CHOO}\right)$, hydroxyethoxy $\left(\mathrm{CH}_{3} \mathrm{CHOOH}\right)$, and ethoxy hemiacetal $\left(\mathrm{CH}_{3} \mathrm{CHOOC}_{2} \mathrm{H}_{5}\right)$ all prefer to adsorb at the surface through their $\mathrm{O}$ atoms coordinated with the surface in a bridged structure. The hydroxyl also tends to coordinate to the surface through its $\mathrm{O}$ atom but at bridge site of the surface. Atomic hydrogen and

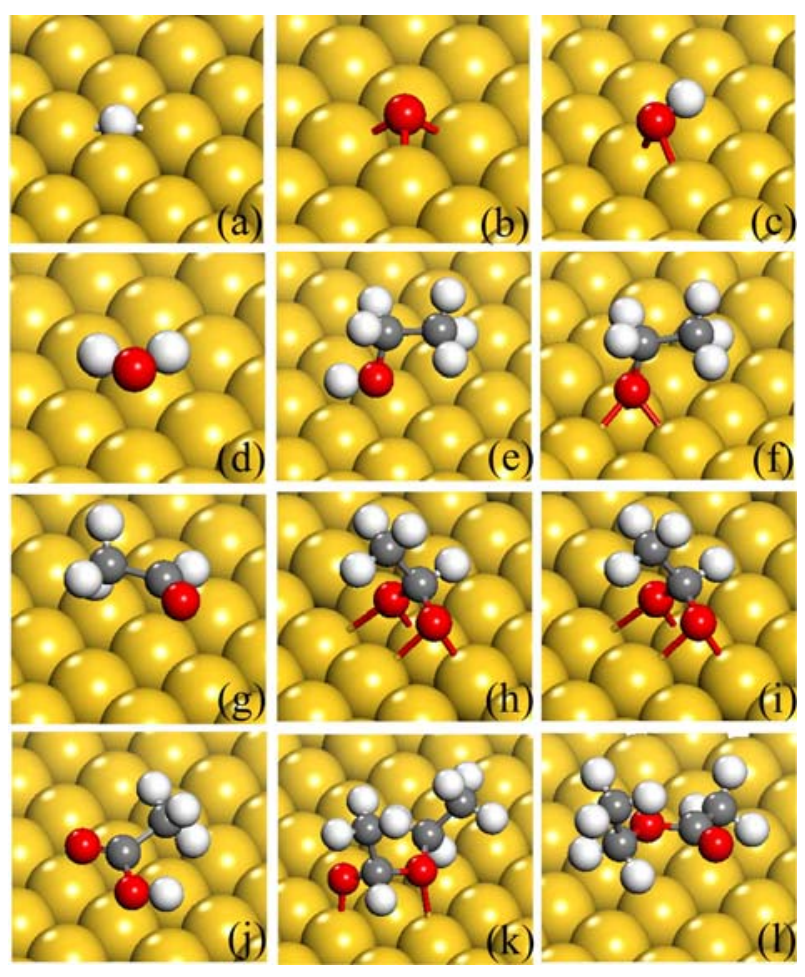

Fig. 1. Species involved in the selective oxidation of ethanol on $\mathrm{Au}(111)$ at their favorable sites. (a) Hydrogen atom; (b) Oxygen atom; (c) Hydroxyl; (d) Water; (e) Ethanol; (f) Ethoxy; (g) Acetaldehyde; (h) Bidentate acetate; (i) Hydroxyethoxy; (j) Acetic acid; (k) Ethoxy hemiacetal; (1) Ethyl acetate. Big gray for $\mathrm{Au}$; Small gray for $\mathrm{C}$; Small black for O; Small white for $\mathrm{H}$.

oxygen are energetically favorable to adsorb at the fcc hollow sites. Comparing with water, ethanol, acetaldehyde, acetic acid, and ethyl acetate, these intermediates have stronger interactions with the surface.

\subsection{Diffusion}

All relevant elementary steps in the selective oxidation of ethanol on $\mathrm{Au}(111)$ surface involve several species on the surface; therefore, it is important to evaluate the energy cost associated with diffusion on the surface and rearrangement into the starting configurations used for the calculations. Calculated diffusion barriers of various surface species among different adsorption configurations are summarized in Table 2. We note that the diffusion barriers of most surface species are too small to play a significant role in limiting the reaction rate.

The low diffusion barriers of the surface species, which could be a consequence of their weak bonding to $\mathrm{Au}$, indicate that rearrangement and movement of these species from the preferred adsorption sites to the configurations that are necessary for reactions occur readily. On this basis, several pathways corresponding to different reactant and prod- 
Table 2 Diffusion pathways among different adsorption configurations and highest activation barriers on the surface species

\begin{tabular}{lcc}
\hline Species & Diffusion pathway & $\begin{array}{c}\text { Activation } \\
\text { barrier }^{\mathrm{a}} \\
(\mathrm{eV})\end{array}$ \\
\hline $\begin{array}{l}\text { Ethanol, aldehyde, acetic } \\
\text { acid and ethyl acetate }\end{array}$ & - & $<0.05$ \\
$\mathrm{H} \cdot$ & $\mathrm{hcp} \leftrightarrow$ bridge $\leftrightarrow$ fcc & 0.12 \\
$\mathrm{O} \cdot$ & $\mathrm{hcp} \leftrightarrow$ bridge $\leftrightarrow$ fcc & 0.48 \\
OH & $\mathrm{hcp} \leftrightarrow$ bridge $\leftrightarrow$ fcc & 0.19 \\
Ethoxy & top $\leftrightarrow$ bridge $\leftrightarrow$ hcp $\leftrightarrow$ fcc & 0.18 \\
Ethoxy hemiacetal & bridge $\leftrightarrow$ hcp $\leftrightarrow$ fcc $\leftrightarrow$ bridged & 0.27 \\
Hydroxyethoxy & bridge $\leftrightarrow$ hcp $\leftrightarrow$ fcc $\leftrightarrow$ bridged & 0.20 \\
Bidentate acetate & fcc $\leftrightarrow$ bidentate $\leftrightarrow$ hcp & 0.75 \\
\hline
\end{tabular}

${ }^{\mathrm{a}} \mathrm{We}$ calculated both the forward and the reverse reactions between each two adsorption configurations, and only the highest barriers (including zero-point energy) are listed in the table.

${ }^{\mathrm{b}}$ As the molecular species weakly adsorb on the surface without a strong energetic preference for either orientation or binding site, their diffusion pathways are complex and hardly to describe.

uct configurations were considered for each elementary reaction and only the pathways with the lowest barriers were discussed below. Additionally, because the diffusion barriers of $\mathrm{O}$ atoms from fcc site to other sites are higher than the reaction barrier of the rate limiting step (to be discussed below), the most stable adsorption site, fcc site, was chosen as the adsorption site for $\mathrm{O}$ atom in all configurations. The diffusion barriers of bidentate acetate species from the hcp or fcc site to the bidentate configuration are all lower than $0.05 \mathrm{eV}$.

\subsection{Activation barriers and reaction energies of elementary steps}

Several key elementary reactions in the O-assisted selective oxidation of ethanol on $\mathrm{Au}(111)$ are considered, including (i) activation of ethanol to ethoxy, (ii) $\beta$-H elimination of ethoxy to acetaldehyde, (iii) nucleophilic attack of O/hydroxyl/ethoxy to acetaldehyde to form bidentate acetate/hydroxyethoxy/ethoxy hemiacetal, (iv) $\beta$-H elimination of hydroxyethoxy/ethoxy hemiacetal to acetic acid/ethyl acetate, and (v) isomerization of bidentate acetate to form acetic acid. The activation barriers $\left(E_{\mathrm{a}}\right)$ and reaction energies $\left(E_{\mathrm{r}}\right)$ of the elementary reactions are summarized in Table 3 .

\subsubsection{Activation of ethanol to ethoxy}

As the first step of selective oxidation of ethanol on $\mathrm{Au}(111)$, the activation of the $\mathrm{O}-\mathrm{H}$ bond to form adsorbed ethoxy $\left(\mathrm{CH}_{3} \mathrm{CH}_{2} \mathrm{O}\right)$ has been identified employing vibrational spectroscopy [8]. In our calculations, three different reaction routes for oxidation of ethanol to ethoxy were considered (Fig. 2): dissociation of ethanol to ethoxy, $\mathrm{O}$-assisted activation of ethanol to ethoxy, and $\mathrm{OH}$-assisted activation of ethanol to ethoxy (entries 1-3, Table 3).

Transfer of $\mathrm{H}$ atom to the clean Au surface is not favorable, as suggested by the computed activation barrier (2.11 $\mathrm{eV}$ ), and this reaction is strongly endothermic by $2.01 \mathrm{eV}$. In the TS structure, the $\mathrm{H}$ atom is shared by the ethoxy and the Au surface (Fig. 2(b)). Upon completion of the reaction, the ethoxy relaxes to an upright configuration, and the $\mathrm{H}$ atom

Table $3 E_{\mathrm{a}}$ and $E_{\mathrm{r}}$ for possible reaction pathways involved in the ethanol selective oxidation on $\mathrm{Au}(111)$

\begin{tabular}{|c|c|c|c|}
\hline Entry & Reaction pathway & $E_{\mathrm{a}}^{* *} / \mathrm{eV}$ & $E_{\mathrm{r}}^{* *} / \mathrm{eV}$ \\
\hline 1 & $\mathrm{CH}_{3} \mathrm{CH}_{2} \mathrm{OH} \rightarrow \mathrm{CH}_{3} \mathrm{CH}_{2} \mathrm{O}^{*}+\mathrm{H}^{*}$ & 2.11 & 2.01 \\
\hline 2 & $\mathrm{CH}_{3} \mathrm{CH}_{2} \mathrm{OH}+\mathrm{O}^{*} \rightarrow \mathrm{CH}_{3} \mathrm{CH}_{2} \mathrm{O}^{*}+\mathrm{O}^{*} \mathrm{H}$ & 0.20 & 0.04 \\
\hline 3 & $\mathrm{CH}_{3} \mathrm{CH}_{2} \mathrm{OH}+\mathrm{O}^{*} \mathrm{H} \rightarrow \mathrm{CH}_{3} \mathrm{CH}_{2} \mathrm{O}^{*}+\mathrm{H}_{2} \mathrm{O}$ & 0.17 & 0.08 \\
\hline 4 & $\mathrm{CH}_{3} \mathrm{CH}_{2} \mathrm{O}^{*} \rightarrow \mathrm{CH}_{3} \mathrm{CHO}+\mathrm{H}^{*}$ & 2.52 & -0.47 \\
\hline 5 & $\mathrm{CH}_{3} \mathrm{CH}_{2} \mathrm{O}^{*}+\mathrm{O}^{*} \rightarrow \mathrm{CH}_{3} \mathrm{CHO}+\mathrm{O}^{*} \mathrm{H}$ & 0.29 & -2.56 \\
\hline 6 & $\mathrm{CH}_{3} \mathrm{CH}_{2} \mathrm{O}^{*}+\mathrm{O}^{*} \mathrm{H} \rightarrow \mathrm{CH}_{3} \mathrm{CHO}+\mathrm{H}_{2} \mathrm{O}$ & 0.67 & -2.62 \\
\hline 7 & $\mathrm{CH}_{3} \mathrm{CH}_{2} \mathrm{O}^{*}+\mathrm{CH}_{3} \mathrm{CH}_{2} \mathrm{O}^{*} \rightarrow \mathrm{CH}_{3} \mathrm{CHO}+\mathrm{CH}_{3} \mathrm{CH}_{2} \mathrm{OH}$ & 0.27 & -0.45 \\
\hline 8 & $\mathrm{CH}_{3} \mathrm{CHO}+\mathrm{O}^{*} \rightarrow \mathrm{CH}_{3} \mathrm{CHO}^{*} \mathrm{O}^{*}$ & 0.36 & 0.35 \\
\hline 9 & $\mathrm{CH}_{3} \mathrm{CHO}+\mathrm{O}^{*} \mathrm{H} \rightarrow \mathrm{CH}_{3} \mathrm{CHO}^{*} \mathrm{O}^{*} \mathrm{H}$ & 0.19 & -0.48 \\
\hline 10 & $\mathrm{CH}_{3} \mathrm{CH}_{2} \mathrm{O}^{*}+\mathrm{CH}_{3} \mathrm{CHO} \rightarrow \mathrm{CH}_{3} \mathrm{CHO}^{*} \mathrm{OCH}_{2} \mathrm{CH}_{3}$ & 0.24 & -0.40 \\
\hline 11 & $\mathrm{CH}_{3} \mathrm{CHO}^{*} \mathrm{O}^{*} \mathrm{H} \rightarrow \mathrm{CH}_{3} \mathrm{COOH}+\mathrm{H}^{*}$ & 2.00 & -0.88 \\
\hline 12 & $\mathrm{CH}_{3} \mathrm{CHO}{ }^{*} \mathrm{OH}+\mathrm{O}^{*} \rightarrow \mathrm{CH}_{3} \mathrm{COOH}+\mathrm{O}^{*} \mathrm{H}$ & 1.34 & -2.78 \\
\hline 13 & $\mathrm{CH}_{3} \mathrm{CHO}^{*} \mathrm{OH}+\mathrm{O}^{*} \mathrm{H} \rightarrow \mathrm{CH}_{3} \mathrm{COOH}+\mathrm{H}_{2} \mathrm{O}$ & 0.91 & -2.92 \\
\hline 14 & $\mathrm{CH}_{3} \mathrm{CHO}^{*} \mathrm{O}^{*} \rightarrow \mathrm{CH}_{3} \mathrm{COOH}$ & 0.28 & -3.41 \\
\hline 15 & $\mathrm{CH}_{3} \mathrm{CHO}^{*} \mathrm{O}^{*} \mathrm{CH}_{2} \mathrm{CH}_{3} \rightarrow \mathrm{CH}_{3} \mathrm{COOCH}_{2} \mathrm{CH}_{3}+\mathrm{H}^{*}$ & 1.26 & -1.22 \\
\hline 16 & $\mathrm{CH}_{3} \mathrm{CHO}^{*} \mathrm{OCH}_{2} \mathrm{CH}_{3}+\mathrm{O}^{*} \rightarrow \mathrm{CH}_{3} \mathrm{COOCH}_{2} \mathrm{CH}_{3}+\mathrm{O}^{*} \mathrm{H}$ & 0.00 & -3.22 \\
\hline 17 & $\mathrm{CH}_{3} \mathrm{CHO}^{*} \mathrm{O}^{*} \mathrm{CH}_{2} \mathrm{CH}_{3}+\mathrm{O}^{*} \mathrm{H} \rightarrow \mathrm{CH}_{3} \mathrm{COOCH}_{2} \mathrm{CH}_{3}+\mathrm{H}_{2} \mathrm{O}$ & 0.67 & -3.22 \\
\hline
\end{tabular}

*The species adsorbed on the surface through these atoms.

**Zero point energies are included. 


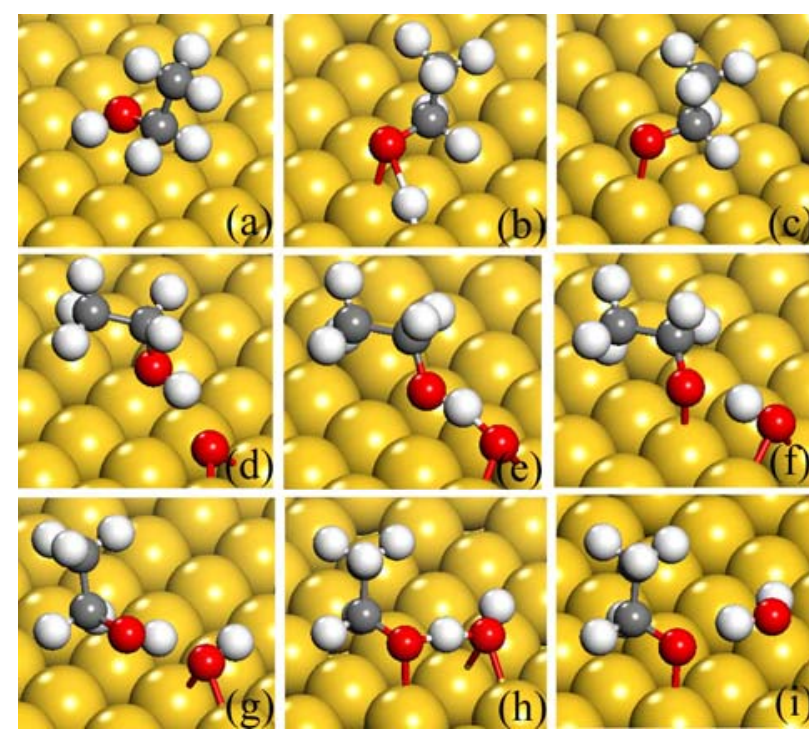

Fig. 2. Configuration of reactant (a, d, g), transition state (b, e, h), and product (c, $f, i)$ of activation of ethanol to ethoxy. $(a-c)$ Direct dissociation of ethanol; $(\mathrm{d}-\mathrm{f}) \mathrm{O}$-assisted activation; (g-i) $\mathrm{OH}$-assisted activation.

diffuses to a nearby fcc site (Fig. 2(c)). Indeed, it has observed experimentally that atomic oxygen is necessary to activate the $\mathrm{O}-\mathrm{H}$ bond in ethanol and other alcohols, and molecular adsorption of ethanol is fully reversible on the clean $\mathrm{Au}(111)$ surface $[8,17]$. Additionally, we find that the reactant configuration of the $\mathrm{O}$-assisted activation of ethanol to ethoxy corresponds to the ethanol adsorbed at the top site near an $\mathrm{O}$ adatom (Fig. 2(d)). The configuration of ethoxy adsorbed at top site and hydroxyl adsorbed at the bridge site nearby was created for the product (Fig. 2(f)). The calculated energy barrier was $0.20 \mathrm{eV}$ (Table 3), which is lower than that $(0.41 \mathrm{eV})$ for the $\mathrm{O}$-assisted activation of methanol reported earlier [57]. The calculated value is in excellent agreement with the experimental result [25]. Notably, the presence of the surface $\mathrm{O}$ atom reduces the reaction energy greatly from 2.11 to $0.04 \mathrm{eV}$.

We have also examined the possibility for the third route, surface hydroxyl-assisted activation of ethanol to ethoxy, to fully understand the process of this reaction. The presence of $\mathrm{OH}$ species significantly reduces the reaction energy from 2.11 to $0.08 \mathrm{eV}$. Specifically, ethanol starts to adsorb on a distorted atop site near the $\mathrm{OH}$ species that adsorbed on a bridge site (Fig. 2(g)). The calculated energy barrier, 0.17 $\mathrm{eV}$, indicates that transfer an $\mathrm{H}$ atom to the neighboring $\mathrm{OH}$ species is facile. In the transition-state configuration (Fig. 2(h)), the hydrogen is shared by ethanol and hydroxyl.

\subsection{2 $\beta$-H elimination of ethoxy to acetaldehyde}

As the main product of selective oxidation of ethanol, acetaldehyde is considered to be formed through the $\beta-\mathrm{H}$ elimination of ethoxy [8,17]. In our calculations, four different routes were compared: (i) transfer of $\mathrm{H}$ from ethoxy to $\mathrm{Au}(111)$ surface to produce acetaldehyde (entry 4, Table 3); (ii) transfer of $\mathrm{H}$ from ethoxy to adsorbed $\mathrm{O}$ atom, yielding a transient $\mathrm{OH}$ species and acetaldehyde (entry 5, Table 3); (iii) transfer of $\mathrm{H}$ from ethoxy to surface hydroxyl, affording water and acetaldehyde (entry 6, Table 3); (iv) transfer of $\mathrm{H}$ from ethoxy to a second ethoxy, generating acetaldehyde and ethanol (entry 7, Table 3).

In all the pathways except entry 7, ethoxy starts from a hollow site and then tilts toward the species to which $\mathrm{H}$ is transferred, that is $\mathrm{O}, \mathrm{OH}$, or the Au surface. And for entry 7 , the reaction starts from two ethoxy both adsorbed at top sites (Fig. 3(j)) with the $\mathrm{C}-\mathrm{C}$ bond vertical to the substrate. In the TS structures (Fig. 3), $\mathrm{H}$ is shared between the carbon atom in the ethoxy and the oxygen atom in the species receiving the $\mathrm{H}$ or the surface. The calculated energy barriers for these reactions range between 2.52 and $0.27 \mathrm{eV}$ (Table 3).

At low surface temperature (e.g., $<245 \mathrm{~K}[8]$ ), the dynamic favorable reaction pathways are the transfer of a $\beta-\mathrm{H}$ to $\mathrm{O}$ adatom or to another ethoxyl, and the energy barriers are 0.29 and $0.27 \mathrm{eV}$, respectively. Notably, both of two energy barriers are lower than that $(0.49 \mathrm{eV})$ for the forma-

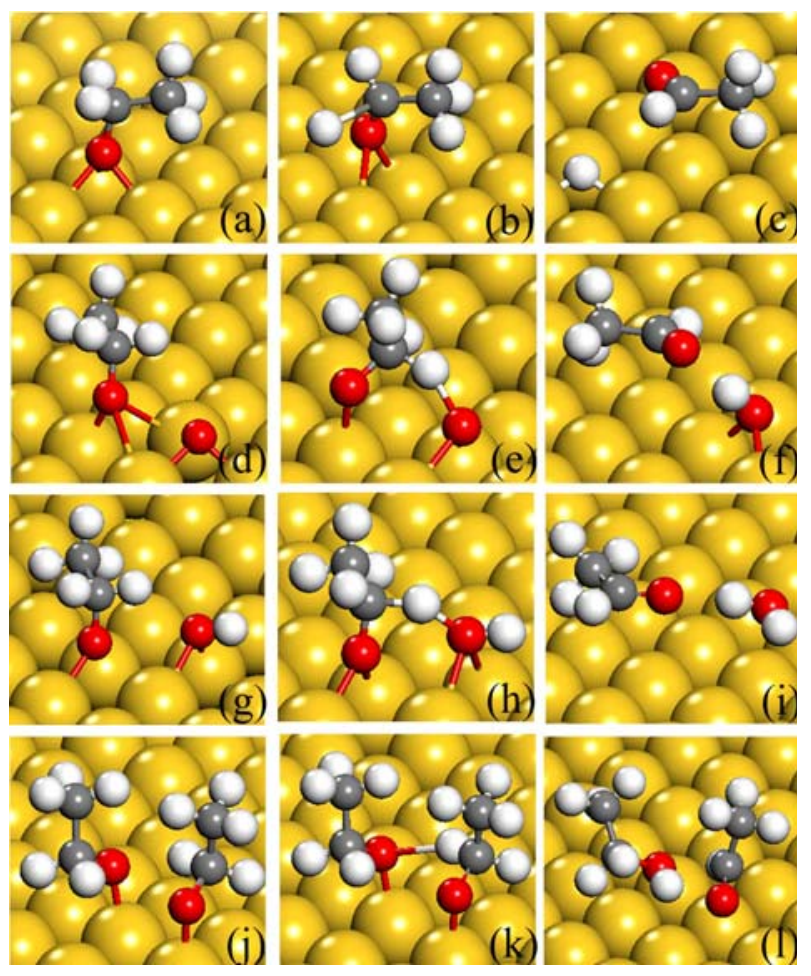

Fig. 3. Configuration of reactant (a, d, g, j), transition state (b, e, h, $\mathrm{k}$ ), and product (c, $\mathrm{f}, \mathrm{i}, \mathrm{l})$ of $\beta$-H elimination of ethoxy to form acetaldehyde. (a-c) Directly transfer of $\mathrm{H}$ to Au surface; (d-f) Transfer of $\mathrm{H}$ to adsorbed $\mathrm{O}$ atom; $(\mathrm{g}-\mathrm{i})$ Transfer of $\mathrm{H}$ to surface hydroxyl; $(\mathrm{j}-1)$ Transfer of $\mathrm{H}$ to another ethoxy. 
tion of formaldehyde through $\beta-\mathrm{H}$ elimination of methoxy [57], and this result is well agreed with the experimental result that the rate of $\beta-\mathrm{H}$ elimination from methoxy is slower than that of ethoxy [25]. Additionally, the transfer of $\beta-\mathrm{H}$ is thermodynamically favorable; the product energy relative to the starting reactant is -2.56 (entry 4 , Table 3 ) and $-0.45 \mathrm{eV}$ (entry 7 , Table 3 ), respectively.

\subsubsection{Esterification}

Formation of ethyl acetate from reaction of ethoxy and acetaldehyde was observed experimentally on $\mathrm{O} / \mathrm{Au}(111)$ [8]. In our calculations, the reaction pathway for the formation of ethyl acetate was separated into two steps: nucleophilic attack of ethoxy to acetaldehyde to form ethoxy hemiacetal (entry 10, Table 3) and $\beta-\mathrm{H}$ elimination of ethoxy hemiacetal to ethyl acetate (entries 15-17, Table 3).

Calculated activation barrier for reaction of ethoxy and acetaldehyde on $\mathrm{Au}(111)$ surface is $0.24 \mathrm{eV}$ (Table 3). The product, adsorbed ethoxy hemiacetal, is $0.40 \mathrm{eV}$ more stable than the separated reactants. In the starting configurations, the ethoxy is bound to an fcc site via the oxygen atom and acetaldehyde weakly adsorbs on the surface without a strong energetic preference for either orientation or binding site (Fig. 4(a)). When acetaldehyde is close to the ethoxy with the carbon end facing the ethoxy (Fig. 4(b)), the ethoxy tilts so that the oxygen atom can attack the electron deficient carbon atom in acetaldehyde, resulting in the forma- tion of the ethoxy hemiacetal intermediate, bounding to the surface via an fcc site through its $\mathrm{O}$ atom of $\mathrm{C}=\mathrm{O}$ (Fig. $4(c))$. It may diffuse to the preferable configuration, bridged structure (Fig. 1(k)), by crossing a $0.21 \mathrm{eV}$ energy barrier.

The final step in the formation of ethyl acetate is the loss of a hydrogen atom bound to ethyl acetate from the ethoxy hemiacetal intermediate, based on the mechanism reported by Friend and co-workers [8]. The calculated barrier for the formation of ethyl acetate via this process is $1.26 \mathrm{eV}$ (Table 3 ), which indicates that the surface-assisted $\beta-\mathrm{H}$ elimination of ethoxy hemiacetal to ethyl acetate is not facile. In the TS configuration, the $\mathrm{H}$ atom is shared by the surface and ethyl acetate (Fig. 4(e)). Furthermore, the reaction is thermodynamically downhill by $1.22 \mathrm{eV}$.

The activation barrier for transfer of $\beta$ - $\mathrm{H}$ from the hemiacetal to the surface hydroxyl is $0.66 \mathrm{eV}$ (Table 3 ), and in the TS configuration, the $\mathrm{H}$ atom is shared by the $\mathrm{OH}$ species and the ethyl acetate (Fig. 4(i)). This result is somewhat different from the work regarding the formation of methyl formate by the $\mathrm{OH}$-assisted $\beta-\mathrm{H}$ elimination of alkoxy hemiacetal to methyl formate where no activation barrier was reported [57]. Moreover, the presence of the surface hydroxyl also increases the energy gain from 1.22 to $3.22 \mathrm{eV}$ (Table 3).

Notably, the loss of a $\mathrm{H}$ atom from the hemiacetal to adsorbed $\mathrm{O}$ atom has no barrier from the staring configuration considered (Fig. 4(g)), and the reaction pathway described by entry 16 has a large energy gain, $3.22 \mathrm{eV}$ (Table 3 ). This
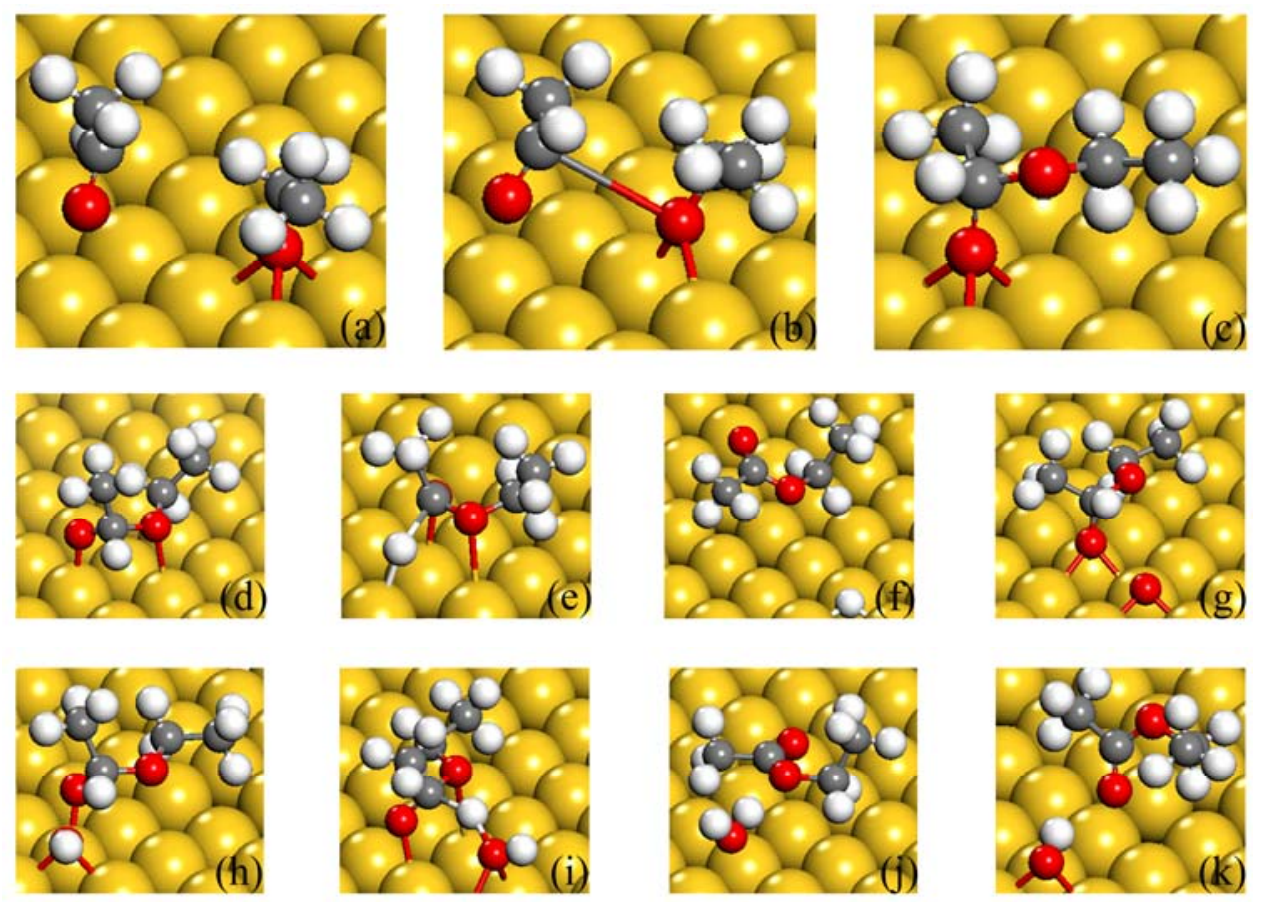

Fig. 4. Configuration of reactant (a, d, g, h), transition state (b, e, i), and product (c, f, j, k) for the formation of ethyl acetate. (a-c) Nucleophilic attack of ethoxy to acetaldehyde to form ethoxy hemiacetal; $(\mathrm{d}-\mathrm{f})$ Directly transfer of $\mathrm{H}$ to Au surface; (g, $\mathrm{k}$ ) Transfer of $\mathrm{H}$ to adsorbed $\mathrm{O}$ atom; (h-j) Transfer of $\mathrm{H}$ to surface hydroxyl. 
result is consistent with experimental data that the rate limiting step of oxidation of ethanol on gold is the subsequent $\beta-\mathrm{H}$ bond cleavage in the ethoxy to form the adsorbed acetaldehyde [8,17]. Furthermore, replacing $\mathrm{O}$ atom with $\mathrm{OH}$ species in the elimination of the $\mathrm{CH}_{3} \mathrm{CHOOC}_{2} \mathrm{H}_{5}$ intermediate would change the activation barrier greatly, indicating that the $\mathrm{O}$ adatom is necessary for the formation of the ester upon the presence of ethoxy and acetaldehyde species.

\subsubsection{Acidification}

We have also looked at the reaction path of the acidification reaction since it has been reported experimentally that the products of the secondary oxidation of ethanol contain acetic acid and ketene $[8,17]$. Acetic acid is considered as the major product for the further oxidation of acetaldehyde. Two different mechanisms regarding the formation of acetic acid are considered: one is similar with the formation of ethyl acetate, in which acetic acid is formed through the reaction of surface hydroxyl and acetaldehyde, and the elementary step proposed involves the attack of the electron-deficient carbonyl carbon in acetaldehyde by the electron rich oxygen in hydroxyl (entry 9, Table 3) and $\beta-\mathrm{H}$ elimination of hydroxyethoxy to acetic acid (entries 11-13, Table 3). Another pathways is through the reaction of adsorbed $\mathrm{O}$ atom and acetaldehyde, and the elementary step is the attack of acetaldehyde by the adsorbed $\mathrm{O}$ atom to form bidentate acetate intermediate (entry 8 , Table 3 ) and the isomerization of the intermediate to form acetic acid (entry 14, Table 3).

Nucleophilic attack of hydroxyl to acetaldehyde to form hydroxyethoxy starts from the configuration that hydroxyl adsorbed at the bridge site and the acetaldehyde weakly floated on the surface near the hydroxyl (Fig. 5(a)) and ends with the hydroxyethoxy adsorbed on the surface through its hydroxyl $\mathrm{O}$ atom at the bridge site and the remained $\mathrm{O}$ atom at the top site (Fig. 5(c)). The calculated activation barrier is $0.19 \mathrm{eV}$ and the energy gain for this reaction is $0.48 \mathrm{eV}$ (Table 3).

Three possible routes were also considered for the $\beta-\mathrm{H}$ elimination of hydroxyethoxy to acetic acid: (i) transfer of $\mathrm{H}$ atom to the $\mathrm{Au}$ surface, affording acetic acid and adsorbed $\mathrm{H}$ atom (entry 11, Table 3); (ii) transfer of $\mathrm{H}$ atom to the adsorbed $\mathrm{O}$ atom, generating acetic acid and a transient $\mathrm{OH}$ species (entry 12, Table 3); (iii) transfer of $\mathrm{H}$ atom to the surface hydroxyl, yielding acetic acid and water (entry 13, Table 3). Notably, hydroxyethoxy starts from the bridged structure (Fig. 5(d)) in entry 11 but from the fcc site (Figs. 5(g) and (j)) in entries 12 and 13.

Computational barriers for these reaction pathways range between 0.91 and $2.00 \mathrm{eV}$ (Table 3), suggesting that none of the three routes is facile at low temperature (e.g., $<245 \mathrm{~K}$
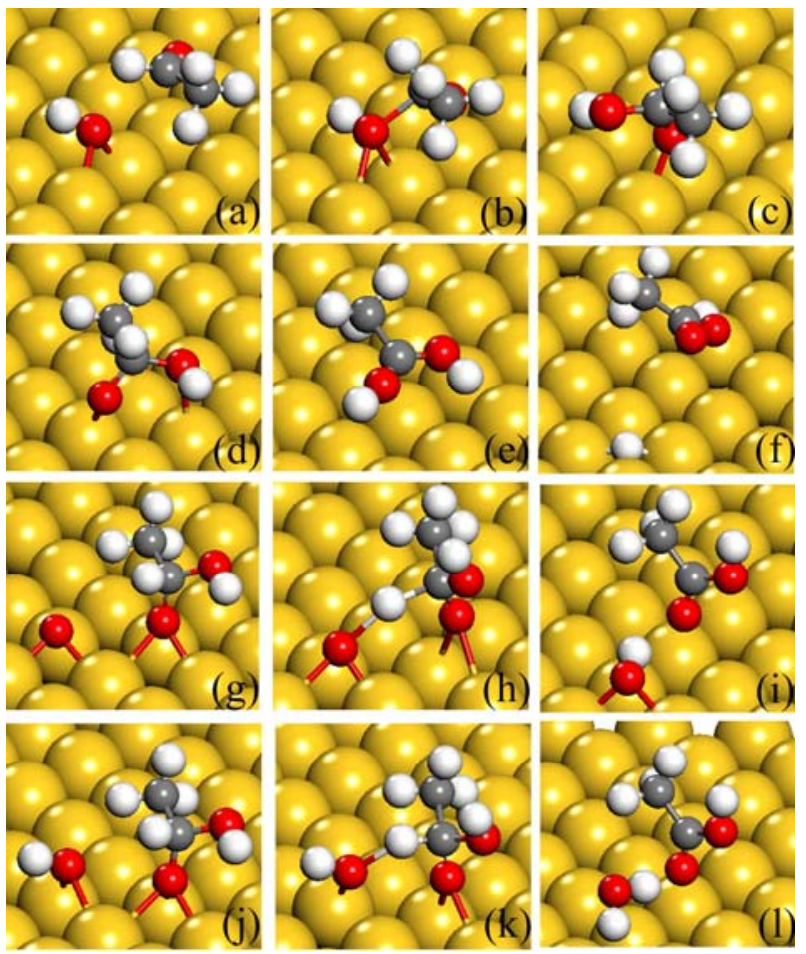

Fig. 5. Configuration of reactant (a, d, g, j), transition state (b, e, h, k), and product $(\mathrm{c}, \mathrm{f}, \mathrm{i}, \mathrm{l})$ for the formation of acetic acid. $(\mathrm{a}-\mathrm{c})$ Nucleophilic attack of hydroxyl to acetaldehyde to form hydroxyethoxy; (d-f) Directly transfer of $\mathrm{H}$ to $\mathrm{Au}$ surface; $(\mathrm{g}-\mathrm{i})$ Transfer of $\mathrm{H}$ to adsorbed $\mathrm{O}$ atom; (j-1) Configuration of transfer of $\mathrm{H}$ to surface hydroxyl.

[8]), which is well agreed with the experimental result [8]. Moreover, the thermodynamic energies for the different reactions are substantially different. The presences of the adsorbed $\mathrm{O}$ atom or $\mathrm{OH}$ species increase the energy gains from 0.88 to 2.78 or $2.92 \mathrm{eV}$ (Table 3 ), respectively.

We need to mention that it is experimentally expected that the acetate moiety and $\mathrm{H}$ atom were the products of the reaction between surface $\mathrm{O}$ atom and acetaldehyde [2]. Figure 6 illustrates a proposed mechanism for the formation of acetic acid through the reaction between the surface $\mathrm{O}$ atom and acetaldehyde. The elementary step involves attack of the electron-deficient carbonyl carbon in acetaldehyde by surface oxygen (entry 8 , Table 3 ). The reaction starts from the configuration that $\mathrm{O}$ atom adsorbs at an fcc site and the acetaldehyde anchors on the top of the $\mathrm{O}$ atom via its $\mathrm{C}$ atom in $\mathrm{C}=\mathrm{O}$ (Fig. 6(a)), and ends with the bidentate acetate adsorbed in an fcc site (Fig. 6(c)). The calculated energy barrier was $0.36 \mathrm{eV}$, implying that the reaction is facile. However, we notice that activation energy for the reverse reaction of entry 8 is lower than $0.05 \mathrm{eV}$, which suggests that the bidentate acetate intermediate is not stable in the fcc site. Furthermore, the diffusional energy barrier of the bidentate acetate from the fcc site to bridged configuration (Fig. 1(e)) is also lower than $0.05 \mathrm{eV}$, and the process has a 


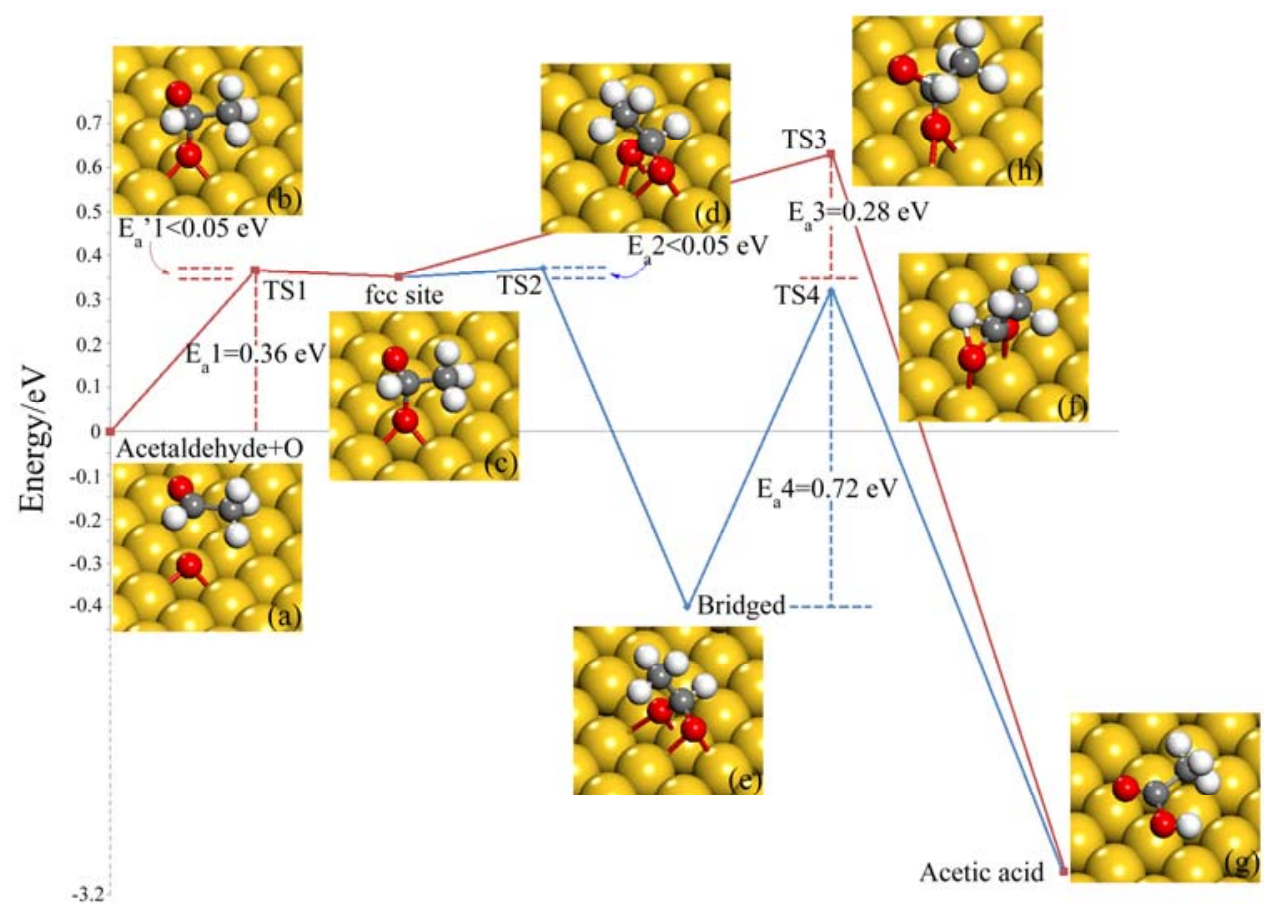

- Path for the acetic acid formation through the bidentate acetate at bridged structure

- Path for the acetic acid formation through the bidentate acetate at fcc site

Fig. 6. Overall catalytic pathways for the surface $\mathrm{O}$ atom attacked acetaldehyde to form acetic acid. $(\mathrm{a}-\mathrm{c})$ Reactant, transition state, and product structures for the formation of fcc adsorbed bidentate acetate by surface $\mathrm{O}$ and acetaldehyde; (d,e) Transition state and product structures for the diffusion of bidentate acetate from fcc site to bridged configuration; ( $f, g$ ) Transition state and product structures for the isomerization of bidentate acetate in bridged configuration to form acetic acid; (h) Transition state configuration for the isomerization of bidentate acetate adsorbed at fcc site to form acetic acid. Zero energy reference is corresponding coadsorption configuration of $\mathrm{O}$ atom and acetaldehyde on $\mathrm{Au}(111)$ surface.

large energy gain (i.e., $0.75 \mathrm{eV}$ ). Therefore, it is very likely that the bidentate acetate intermediate will intermediately go back to separate reactants or transfer to a bridged adsorption configuration upon formation.

The final step in the formation of acetic acid, the isomerization of bidentate acetate to form acetic acid, has a calculated energy barrier of $0.28 \mathrm{eV}$ if the bidentate acetate intermediate starts from the fcc site or $0.72 \mathrm{eV}$ if it starts from the bridged adsorption configuration (Fig. 6, $E_{\mathrm{a}} 3$ and $\left.E_{\mathrm{a}} 4\right)$. Considering that the intermediate is not stable at fcc site and may transfer to bridged adsorption configuration rapidly is we discussed above, we expect that the formation of acetic acid is not readily due to the high energy barrier of isomerization from the bidentate adsorption configuration.

\section{Conclusions}

We have examined reaction pathways for selective oxidation of ethanol on the $\mathrm{Au}(111)$ surface via a comprehensive periodic density functional theory calculations. Various adsorption modes of the intermediates involved in the reaction were investigated, and from the energetic and geometrical points of views, the selective oxidation mechanism has been clarified. We have found that the diffusion for most of the surface species is rapid and facilitates the reactions leading to selective oxidation. Surface oxygen adatom is necessary in the $\mathrm{O}-\mathrm{H}$ bond activation of ethanol, consistent with experimental observations. We have also obtained evidence showing that the activation barrier of the $\beta-\mathrm{H}$ elimination of ethoxy is higher than activation of ethanol and formation of ethyl acetate. Additionally, the formation of the acetic acid is not facile through the reaction between the adsorbed $\mathrm{O}$ atom and acetaldehyde due to the high activation barrier.

\section{References}

1 Haruta M. Catal Today, 1997, 36: 153

2 Bond G C, Thompson D T. Catal Rev-Sci Eng, 1999, 41: 319

3 Stephen A, Hashmi K, Hutchings G J. Angew Chem, Int Ed, 2006, 45: 7896

4 Min B K, Friend C M. Chem Rev, 2007, 107: 2709

5 Gong J, Mullins C B. Acc Chem Res, 2009, 42: 1063

6 Gong J. Chem Rev, 2012, in press

7 Xu B, Liu X, Haubrich J, Madix R J, Friend C M. Angew 
Chem, Int Ed, 2009, 48: 4206

8 Liu X, Xu B, Haubrich J, Madix R J, Friend C M. J Am Chem Soc, 2009, 131: 5757

9 Della Pina C, Falletta E, Rossi M. ChemSusChem, 2009, 2: 57

10 Yang X, Wang X, Liang C, Su W, Wang C, Feng Z, Li C, Qiu J. Catal Commun, 2008, 9: 2278

11 Wang X, Kawanami H, Dapurkar S E, Venkataramanan N S, Chatterjee M, Yokoyama T, Ikushima Y. Appl Catal A, 2008, 349: 86

12 Wang L-C, Liu Y-M, Chen M, Cao Y, He, Fan K-N. J Phys Chem C, 2008, 112: 6981

13 Su F-Z, Liu Y-M, Wang L-C, Cao Y, He H-Y, Fan K-N. Angew Chem, Int Ed, 2008, 47: 334

14 Klitgaard S K, DeLa Riva A T, Helveg S, Werchmeister R M, Christensen C H. Catal Lett, 2008, 126: 213

15 Abad A, Almela C, Corma A, García H. Tetrahedron, 2006, 62: 6666

16 Abad A, Corma A, Garcia H. Pure Appl Chem, 2007, 79: 1847

17 Gong J, Mullins C B. J Am Chem Soc, 2008, 130: 16458

18 Jørgensen B, Egholm Christiansen S, Dahl Thomsen M L, Christensen C H. J Catal, 2007, 251: 332

19 Gong J, Flaherty D W, Ojifinni R A, White J M, Mullins C B. J Phys Chem C, 2008, 112: 5501

20 Hutchings G J. Chem Commun, 2008: 1148

21 Sinha A K, Seelan S, Tsubota S, Haruta M. Top Catal, 2004, 29: 95

22 Lambert R M, Williams F J, Cropley R L, Palermo A. J Mol Catal A, 2005, 228: 27

23 Deng X, Min B K, Liu X, Friend C M. J Phys Chem B, 2006, 110: 15982

24 Hayashi T, Tanaka K, Haruta M. J Catal, 1998, 178: 566

$25 \mathrm{Xu}$ B, Madix R J, Friend C M. J Am Chem Soc, 2010, 132: 16571

$26 \mathrm{Xu} \mathrm{B}$, Haubrich J, Freyschlag C G, Madix R J, Friend C M. Chem Sci, 2010, 1: 310

$27 \mathrm{Xu} \mathrm{B}$, Zhou L, Madix R J, Friend C M. Angew Chem, Int Ed, 2010, 122: 404

$28 \mathrm{Xu}$ B, Liu X, Haubrich J, Friend C M. Nat Chem, 2010, 2: 61

29 Mallat T, Baiker A. Chem Rev, 2004, 104: 3037

30 Yamaguchi K, Mizuno N. Chem Eur J, 2003, 9: 4353

31 Yamaguchi K, Mizuno N. Angew Chem, Int Ed, 2002, 41: 4538

32 Zhang C, Chen P, Liu J, Zhang Y, Shen W, Xu H, Tang Y. Chem Commun, 2008: 3290

33 Shimizu K-i, Sugino K, Sawabe K, Satsuma A. Chem Eur J, 2009, 15: 2341

34 Zaccheria F, Ravasio N, Psaro R, Fusi A. Chem Eur J, 2006,
12: 6426

35 Huang L, Zhu Y, Huo C, Zheng H, Feng G, Zhang C, Li Y. J Mol Catal A, 2008, 288: 109

36 Carrettin S, McMorn P, Johnston P, Griffin K, Hutchings G J. Chem Commun, 2002: 696

37 Abad A, Concepción P, Corma A, García H. Angew Chem, Int Ed, 2005, 44: 4066

38 Abad A, Corma A, García H. Chem Eur J, 2008, 14: 212

39 Pina D C, Falletta E, Rossi M. J Catal, 2008, 260: 384

40 Guan Y, Hensen E J M. Appl Catal A, 2009, 361: 49

41 Mori K, Hara T, Mizugaki T, Ebitani K, Kaneda K. J Am Chem Soc, 2004, 126: 10657

42 Grunwaldt J-D, Caravati M, Baiker A. J Phys Chem B, 2006, 110: 25586

43 Ferri D, Mondelli C, Krumeich F, Baiker A. J Phys Chem B, 2006, 110: 22982

44 Comotti M, Pina D C, Matarrese R, Rossi M. Angew Chem, Int Ed, 2004, 43: 5812

45 Villa A, Wang D, Dimitratos N, Su D, Trevisan V, Prati L. Catal Today, 2010, 150: 8

46 Kanaoka S, Yagi N, Fukuyama Y, Aoshima S, Tsunoyama H, Tsukuda T, Sakurai H. J Am Chem Soc, 2007, 129: 12060

47 Ishida T, Nagaoka M, Akita T, Haruta M. Chem Eur J, 2008, 14: 8456

48 Liu H, Liu Y, Li Y, Tang Z, Jiang H. J Phys Chem C, 2010, 114: 13362

49 Madix R J, Friend C M, Liu X. J Catal, 2008, 258: 410

50 Outka D A, Madix R J. J Am Chem Soc, 1987, 109: 1708

51 Boronat M, Corma A, Illas F, Radilla J, Ródenas T, Sabater M J. J Catal, 2011, 278: 50

52 Zope B N, Hibbitts D D, Neurock M, Davis R J. Science, 2010, 330: 74

53 Fristrup P, Johansen L B, Christensen C H. Catal Lett, 2008, 120: 184

54 Nielsen I S, Taarning E, Egeblad K, Madsen R, Christensen C H. Catal Lett, 2007, 116: 35

55 Gong J, Flaherty D W, Yan T, Mullins C B. ChemPhysChem, 2008, 9: 2461

56 Chen W-K, Liu S-H, Cao M-J, Yan Q-G, Lu C-H. J Mol Struct, 2006, 770: 87

$57 \mathrm{Xu} \mathrm{B}$, Haubrich J, Baker T A, Kaxiras E, Friend C M. J Phys Chem C, 2011, 115: 3703

58 Perdew J P, Wang Y. Phys Rev B, 1992, 45: 13244

59 Vanderbilt D. Phys Rev B, 1990, 41: 7892

60 Kresse G, Furthmüller J. Phys Rev B, 1996, 54: 11169

61 Monkhorst H J, Pack J D. Phys Rev B, 1976, 13: 5188 